\title{
MIR130B wt Allele
}

National Cancer Institute

\section{Source}

National Cancer Institute. MIR130B wt Allele. NCI Thesaurus. Code C82079.

The human MIR130B wild-type allele is located in the vicinity of chromosome 22 and is approximately 81 bases in length. This allele, which encodes MIR130B pre-miRNA, plays a role in the regulation of gene expression. Alteration in the expression of this gene is associated with the development of hepatocellular carcinoma as well as T-cell leukemia. 